\title{
PENGARUH WAKTU PENGAMBILAN SAMPEL TERHADAP HASIL PEMERIKSAAN KADAR HUMAN CHORIONIC GONADOTROPIN (HCG) PADA IBU HAMIL TRIMESTER 1
}

\author{
Rahmawati $^{1)}$, Nurul Ni’ma Aziz' ${ }^{1}$, Cici Aprianti') \\ ${ }^{1)}$ Politeknik Kesehatan Muhammadiyah Makassar \\ Alamat korenspondensi: rahmawatiamma60@gmail.com
}

\begin{abstract}
Abstrak
Penelitian ini dilatarbelakangi karena kadar Human Chorionic Gonadotropin (HCG) dalam urin pagi lebih pekat dibandingkan urin sewaktu. Urin pagi mencerminkan periode tanpa asupan cairan yang lama, sedangkan urin sewaktu mengalami pengenceran oleh asupan cairan yang masuk kedalam tubuh ibu hamil. Kadar Human Chorionic Gonadotropin (HCG) akan terus meningkat mulai awal kehamilan dan mencapai puncaknya pada minggu ke 10-12 (Trimester I). Penelitian ini bertujuan untuk mengetahui ada atau tidaknya pengaruh waktu pengambilan sampel terhadap hasil pemeriksaan kadar Human Chorionic Gonadotropin (HCG). Jenis penelitian ini bersifat eksperimen laboratorik dengan melakukan pemeriksaan kadar Human Chorionic Gonadotrphin (HCG) dalam urin ibu hamil trimester I menggunakan metode semikuantitatif. Sampel yang diperiksa sebanyak 10 menggunakan urin pagi dan 10 sampel menggunakan urin sewaktu dengan teknik pengambilan sampel yaitu purposive sampling. Analisis data menggunakan program SPSS 20 pada uji t-paired diperoleh hasil $p=0,000<0,05$ artinya Ho ditolak dan Ha diterima, sedangkan analisis data manual uji $t$ dua pihak diperoleh hasil t-hitung $>t$-tabel $(9>2,262)$ artinya terdapat pengaruh yang signifikan dari waktu pengambilan sampel terhadap hasil pemeriksaan kadar Human Chorionic Gonadotropin (HCG) pada ibu hamil trimester I.
\end{abstract}

Kata Kunci: Human Chorionic Gonadotropin (HCG), Urin pagi, Urin Sewaktu, Semi Kuantitatif

\begin{abstract}
This research is motivated because the levels of Human Chorionic Gonadotropin $(H C G)$ in the urine in the morning are more concentrated than urine when. Morning urine reflects a period without long fluid intake, while urine when experiencing dilution by fluid intake into the body of pregnant women. The level of Human Chorionic Gonadotropin (HCG) will continue to increase from the beginning of pregnancy and reach its peak in weeks 10-12 (Trimester I). This study aims to determine whether or not the influence of sampling time on the results of examination of Human Chorionic Gonadotrpin (HCG) levels. This type of research has laboratory experiments by examining levels of Human Chorionic Gonadotropin (HCG) in the urine of pregnant women in the first trimester using a semiquantitative method, where 10 samples were examined using morning urine and 10 samples using urine while the sampling technique was purposive sampling. Analysis of the data using the SPSS 20 t-paired test results obtained $p=0.000<0.05$ means that Ho is rejected and $\mathrm{Ha}$ is accepted, while the t-test analysis of two-party manual data results obtained $t$ count $>t$-table $(9>2.262)$ means there are significant effect from the time of sampling on the results of examination of Human Chorionic Gonadotropin (HCG) levels in trimester I pregnant women.

Keywords: Human Chorionic Gonadotrophin (HCG), Morning Urine, Urine While, Semi Quantitative
\end{abstract}

\section{PENDAHULUAN}

Kehamilan merupakan suatu perubahan dalam rangka melanjutkan keturunan yang terjadi secara alami, menghasilkan janin yang tumbuh di dalam rahim ibu, dan selanjutnya dapat dijelaskan tingkat pertumbuhan dan besarnya janin sesuai pusia kehamilan, pada setiap dilakukan pemeriksaan kahamilan (Muhimah dan Safe'I, 2010 dalam Surya 2015).

Masa kehamilan dimulai dari konsepsi sampai lahirnya janin. Lamanya hamil normal adalah 280 hari (40 minggu atau 9 bulan 7 hari) dihitung dari haid pertama haid terakhir. Kehamilan dibagi dalam 3 trimester pertama dimulai dari hasil konsepsi sampai 3 bulan, trimester 
kedua dimulai dari bulan keempat sampai 6 bulan, trimester ketiga dari bulan ketujuh sampai 9 bulan (Saifuddin, 2008).

Human chorionic gonadotropin (HCG) adalah hormon yang diproduksi oleh trofoblast pada awal kehamilan, hormon ini akan dikeluarkan melalui urin. Adanya HCG dalam urin dapat digunakan untuk deteksi kehamilan dini. Kadar HCG akan semakin meningkat sampai mencapai puncaknya pada kehamilan minggu ke 1012 (Trimester I) dan mencapai kadar terendah saat minggu ke 20 (Harti et al, 2013).

Pada Pemeriksaan kadar HCG ada dua waktu pengambilan sampel yang digunakan, yaitu urin pagi dan urin sewaktu. Yang dimaksudkan dengan urin pagi adalah urin yang pertama tama dikeluarkan pada pagi hari setelah bangun tidur, Urin pagi baik untuk pemeriksaan tes kehamilan berdasarkan adanya human chorionic gonadotropin karena urin satu malam mencerminkan periode tanpa asupan cairan yang lama, sehingga unsurunsur yang terbentuk mengalami pemekatan dalam urin. Sedangkan urin sewaktu adalah urin yang dikeluarkan pada satu waktu yang tidak ditentukan dengan khusus (Gandasoebrata, 2013).

Berdasarkan latar belakang diatas maka peneliti melakukan penelitian tentang "Pengaruh Waktu Pengambilan Sampel Terhadap Hasil Pemeriksaan Kadar Human Chrorionic Gonadotropin (HCG) pada Ibu Hamil Trimester I".

\section{METODE PENELITIAN}

Alat dan Bahan

Alat yang digunakan dalam penelitian ini adalah tabung khan, rak tabung, pipet tetes. Bahan yang digunakan dalam penelitian ini adalah $\mathrm{NaCl}$ fisiologis, urin dan alat strip tes kehamilan (Pregnancy test).

\section{Prosedur Kerja}

Disiapkan 15 tabung khan (sesuai kebutuhan), diisi semua tabung dengan $\mathrm{NaCl}$ fisiologis masing-masing $1 \mathrm{ml}$, kemudian pada tabung 1 diisi dengan sampel urin sebanyak $1 \mathrm{ml}$, dihomogenkan dan $1 \mathrm{ml}$ dipindahkan ke tabung 2, pada tabung 2 larutan $\mathrm{NaCl}$ dan sampel kembali dihomogenkan dan $1 \mathrm{ml}$ dipindahkan ke tabung 3 , cara yang sama dilakukan hingga tabung 15 dan dari tabung 15 dipindahkan $1 \mathrm{ml}$ ke tabung yang lain. Disiapkan alat strip tes kehamilan (Pregnancy test), kemudian dilakukan pengujian secara kualitatif pada tiap tabung sampel yang diencerkan. Pengenceran terus dilanjutkan hingga hasil pengenceran menunjukkan reaksi negatif. Kadar HCG adalah hasil kali pengenceran terakhir yang masih terjadi reaksi positif $\mathrm{x}$ sensitivitas reagen yang digunakan (Nurdin, 2015).

\section{Interpertasi Hasil}

Interpretasi hasil pada strip tes kehamilan, positif: Muncul garis berwarna merah pada garis tes dan garis control, negative: Muncul garis berwarna merah pada garis control dan tidak pada garis tes, invalid: Muncul garis berwarna merah pada garis tes dan tidak pada garis control, atau tidak muncul garis berwarna merah pada garis tes dan garis control.

\section{Analisis Data}

Analisa data disajikan dalam bentuk tabel untuk melihat ada tidaknya pengaruh waktu pengambilan sampel pada pemeriksaan kadar HCG kemudian dilakukan pengujian secara statistic menggunakan uji $\mathrm{t}$ berpasangan program SPSS.

\section{HASIL DAN PEMBAHASAN}

Berdasarkan penelitian yang telah dilakukan dengan jumlah sampel yang diperiksa sebanyak $10 \mathrm{ibu}$ hamil trimester I dengan urin pagi sebanyak 10 cup dan urin sewaktu sebanyak 10 cup, didapatkan hasil sebagai berikut: 
Tabel 1. Hasil Pemeriksaan Kadar Human Chorionic Gonadotropin (HCG) pada Ibu Hamil Trimester I Menggunakan Metode Semikuantitatif.

\begin{tabular}{ccccc}
\hline $\begin{array}{c}\text { Kode } \\
\text { Sampel }\end{array}$ & $\begin{array}{c}\text { Umur } \\
(\text { Th) }\end{array}$ & $\begin{array}{c}\text { PK } \\
(\mathbf{b l n})\end{array}$ & $\begin{array}{c}\text { Urin Pagi } \\
(\mathbf{m I U} / \mathbf{m l})\end{array}$ & $\begin{array}{c}\text { Urin } \\
\text { Sewaktu } \\
(\mathbf{m I U} / \mathbf{m l})\end{array}$ \\
\hline Ny.H & 31 & \pm 3 & 327680 & 163840 \\
Ny. E & 32 & \pm 2 & 163840 & 81920 \\
Ny. A & 24 & \pm 3 & 327680 & 163840 \\
Ny. S & 38 & \pm 2 & 163000 & 81820 \\
Ny. M & 27 & \pm 2 & 327680 & 163840 \\
Ny. En & 27 & \pm 3 & 327680 & 163840 \\
Ny. Hm & 30 & \pm 2 & 327680 & 163840 \\
Ny. Hs & 32 & \pm 3 & 327680 & 163840 \\
Ny. Ms & 23 & \pm 1 & 81920 & 40960 \\
Ny. N & 40 & \pm 3 & 327680 & 163840 \\
\hline
\end{tabular}

*PK: Perkiraan Kehamilan

Berdasarkan hasil pemeriksaan, untuk mendeteksi adanya HCG dalam urine ibu hamil dari 20 sampel urin pagi dan urin sewaktu pada kehamilan trimester I dengan usia kehamilan yang dihitung dari 0 hingga 12 minggu, dimana terjadi perubahan hormonal Human Chorionic Gonadotropin (HCG) sehingga diperoleh hasil yang tinggi.

Tabel 2. Uji hipotesis hasil perhitungan kadar Human Chorionic Gonadotropin (HCG) dalam urin pagi dan urin sewaktu.

\begin{tabular}{ccccc}
\hline Sampel & N & $\begin{array}{c}\text { Sig. (2- } \\
\text { tailed) }\end{array}$ & t-hitung & t-tabel \\
\hline $\begin{array}{l}\text { Urin pagi dan } \\
\text { urin sewaktu }\end{array}$ & 10 & 0.000 & 9 & 2,262 \\
\hline
\end{tabular}

Penelitian ini dilakukan secara eksperimen laboratorik yang bertujuan untuk mengetahui pengaruh waktu pengambilan sampel terhadap hasil pemeriksaan kadar Human Chorionic Gonadotropin (HCG) pada ibu hamil trimester I. Hasil pemeriksaan kadar Human Chorionic Gonadotropin (HCG) disajikan dalam bentuk tabel kemudian dilakukan pengelolahan data secara statistic uji $\mathrm{t}$ berpasangan menggunakan program SPSS 20.

Adanya Human Chorionic Gonadotropin (HCG) dalam urin dapat digunakan sebagai penanda awal kehamilan dan kadar Human Chorionic Gonadotrophin (HCG) yang terlalu tinggi melampaui batas normal dapat diartikan sebagai Mola hidatidosa (hamil anggur).

Kehamilan trimester I adalah usia kehamilan yang dihitung dari 0 hingga 12 minggu, dimana terjadi perubahan hormonal Human Chorionic Gonadotropin (HCG) yang tinggi pada ibu hamil. Perubahan hormonal ini menimbulkan perasaan mual, muntah, pening, serta morning sickness. Tingginya kadar Human Chorionic Gonadotropin $(H C G)$ ini juga dapat mempengaruhi reaksi psikologik dan emosional pada sebagian wanita, misalnya mengalami ketakutan, kecemasan, panik, dan kegusaran terhadap kehamilannya. Hal yang lain yang sering dialami oleh ibu hamil muda adalah meminta makanan yang aneh - aneh yang sebelumnya tidak disukainya (Manuaba, 2013).

Salah satu cara yang dapat dilakukan untuk mengetahui kadar Human Chorionic Gonadotropin (HCG) pada ibu hamil adalah dengan melakukan pemeriksaan kadar Human Chorionic Gonadotropin (HCG) menggunakan metode semikuantitatif. Pemeriksaan kadar Human Chorionic Gonadotropin (HCG) metode semi kuantitatif adalah pemeriksaan yang dilakukan untuk mengetahui kadar Human Chorionic Gonadotropin (HCG) dalam urin. Kelebihan dari pemeriksaan kadar Human Chorionic Gonadotropin (HCG) menggunakan metode semi kuantitatif adalah biaya yang digunakan relatif murah namun terdapat beberapa kekurangan, diantaranya adalah hasil yang diperoleh tidak akurat, proses pemeriksaan membutuhkan waktu cukup lama, dan adanya faktor eksternal yang dapat mempengaruhi hasil pemeriksaan.

Berdasarkan hasil penelitian yang 
telah dilakukan terhadap 10 sampel, diperoleh nilai rata - rata $270320 \mathrm{mIU} / \mathrm{ml}$ untuk pemeriksaan kadar Human Chorionic Gonadotropin (HCG) menggunakan urin pagi dan pemeriksaan kadar Human Chorionic Gonadotropin (HCG) menggunakan urin sewaktu nilai rata - rata yang diperoleh yaitu 135168 $\mathrm{mIU} / \mathrm{ml}$ Hasil ini menunjukkan bahwa nilai rata - rata pemeriksaan menggunakan urin pagi lebih tinggi dan dibandingkan pemeriksaan menggunakan urin sewaktu.

Pemeriksaan kadar Human Chorionic Gonadotropin (HCG) dalam urin sebaiknya menggunakan urin pagi, hal ini dikarenakan urin satu malam mencerminkan periode tanpa asupan cairan yang lama, sehingga kadar Human Chorionic Gonadotropin (HCG) dalam urin lebih tinggi dan mudah dideteksi, sebaliknya jika menggunakan urin sewaktu, kadar Human Chorionic Gonadotropin (HCG) dalam urin akan berkurang dikarenakan urin sewaktu telah mengalami pengenceran oleh asupan cairan yang masuk ke dalam tubuh ibu hamil.

Hasil dari kadar Human Chorionic Gonadotropin (HCG) yang didapatkan dari penelitian ini sesuai dengan kadar normal Human Chorionic Gonadotropin (HCG) dalam urin ibu hamil trimester satu namun pada pemeriksaan menggunakan urin sewaktu terdapat penurunan kadar Human Chorionic Gonadotrohin (HCG) yang kurang dari kadar normalnya.

Hal mendasar yang mempengaruhi hasil pemeriksaan kadar Human Chorionic Gonadotropin (HCG) menggunakan urin pagi dan urin sewakrtu ini adalah perbedaan asupan cairan dari ibu hamil. Urin pagilebih pekat dibandingkan urin sewaktu karena urin pagi mencerminkan periode tanpa asupan cairan yang lama. Sedangkan faktor lain yang mempengaruhi hasil pemeriksaan kadar Human Chorionic Gonadotropin (HCG) adalah cara pemipetan pada saat pengenceran urin dan waktu pembacaan hasil tes kualitatif pada strip tes kehamilan.

Dari data hasil penelitian pada tabel
2, telah dilakukan uji $\mathrm{t}$ berpasangan menggunakan program SPSS 20. Pengambilan keputusan dalam analisis uji t dapat dilakukan dengan dua cara Analisis data menggunakan SPSS dilakukan dengan cara membandingkan nilai p. Dari data yang dihitung, diperoleh hasil p 0,000 $<0,05$ artinya Ho ditolak dan Ha diterima. Sedangkan analisis data secara manual dilakukan dengan cara membandingkan antara t-hitung dan t-tabel. Dari data kadar Human Chorionic Gonadotropin (HCG) yang diperiksa terlihat bahwa t-hitung $>\mathrm{t}$ tabel $(9>2.262)$ sehingga Ho ditolak dan Ha diterima artinya ada pengaruh waktu pengambilan sampel yang signifikan terhadap kadar Human Chorionic Gonadotropin (HCG) pada ibu hamil trimester I.

\section{KESIMPULAN}

Berdasarkan hasil penelitian yang telah dilakukan dengan perhitungan uji $t$ berpasangan menggunakan program SPSS 20 diperolah nilai $\mathrm{p}=0,000<0,05$ artinya Ho ditolak dan Ha diterima. Sedangkan analisis data manual diperoleh hasil thitung $>$ t-tabel $\quad(9>2.262)$ dengan nilai signifikan $95 \%(a=0,05)$ dimana Ho ditolak dan Ha diterima. Dari hasil analisis data tersebut dapat disimpulkan bahwa terdapat pengaruh yang signifikan dari waktu pengambilan sampel terhadap hasil pemeriksaan kadar Human Chorionic Gonadotropin (HCG) pada ibu hamil trimester I.

\section{DAFTAR PUSTAKA}

Gandasoebrata, R. 2013. Penuntun Laboratorium Klinik. Cetakan Kelimabelas. Dian Rakyat. Jakarta.

Harti, dkk. 2013. Pemeriksaan HCG (Human Chorionic Gonadotropin) Untuk Deteksi Kehamilan Dini Secara Immunokromatografi. Jurnal Kesmadaska, (Online), Vol. 4, No.1,(http://jurnal.stikeskusum 
ahusada.ac.id, diunduh 6 April 2016).

Manuaba, IBG. 2013. Ilmu Kebidanan, Penyakit Kandungan dan Keluarga Berencana untuk Pendidikan Bidan. Cetakan Keenam. Penerbit Buku Kedokteran EGC. Jakarta.

Muhimah. 2010. Kecemasan Menghadapi Persalinan (http://repository.usu.ac.id/bits tream/123456789/31776/4/Ch apter\% 20II.pdf, diunduh tanggal 10 April 2016)

Nurdin, 2015. Penuntun Praktikum Imunoserologi I. Akademi Analis Kesehatan

Muhammadiyah. Makassar.

Surya. 2015. Hubungan Tingkat Pendidikan dan Tingkat Pengetahuan Ibu Hamil. Jurnal, (Online), Vol. 07, No.1,(http://www.stikesmuhla. ac.id, diunduh 11 April 2016) 